\title{
Genomic insights into an andean multiresistant soil actinobacterium of biotechnological interest
}

\author{
Daniel Gonzalo Alonso-Reyes ${ }^{1}$. Fátima Silvina Galván ${ }^{1}$ Luciano Raúl Portero ${ }^{1}$ Natalia Noelia Alvarado ${ }^{1}$. \\ María Eugenia Farías ${ }^{2} \cdot$ Martín P. Vazquez $^{3}$. Virginia Helena Albarracín ${ }^{1,4,5}$ (])
}

Received: 10 May 2021 / Accepted: 14 August 2021 / Published online: 31 August 2021

(C) The Author(s), under exclusive licence to Springer Nature B.V. 2021

\begin{abstract}
Central-Andean Ecosystems (between 2000 and $6000 \mathrm{~m}$ above sea level (masl) are typical arid-to-semiarid environments suffering from the highest total solar and ultraviolet-B radiation on the planet but displaying numerous salt flats and shallow lakes. Andean microbial ecosystems isolated from these environments are of exceptional biodiversity enduring multiple severe conditions. Furthermore, the polyextremophilic nature of the microbes in such ecosystems indicates the potential for biotechnological applications. Within this context, the study undertaken used genome mining, physiological and microscopical characterization to reveal the multiresistant profile of Nesterenkonia sp. Act20, an actinobacterium isolated from the soil surrounding Lake Socompa, Salta, Argentina (3570 masl). Ultravioet-B, desiccation, and copper assays revealed the strain's exceptional resistance to all these conditions. Act20's genome presented coding sequences involving resistance to antibiotics, low temperatures, ultraviolet radiation, arsenic, nutrient-limiting conditions, osmotic stress, low atmospheric-oxygen pressure, heavy-metal stress, and toxic fluoride and chlorite. Act20 can also synthesize proteins and natural products such as an insecticide, bacterial cellulose, ectoine, bacterial hemoglobin, and even antibiotics like colicin $\mathrm{V}$ and aurachin $\mathrm{C}$. We also found numerous enzymes for animal- and vegetal-biomass degradation and applications in other industrial processes. The resilience of Act 20 and its biotechnologic potential were thoroughly demonstrated in this work.
\end{abstract}

Keywords Nesterenkonia $\cdot$ Soil $\cdot$ Puna $\cdot$ Genomics $\cdot$ Extremophiles $\cdot$ Biotechnology

Virginia Helena Albarracín

cime@tucuman-conicet.gov.ar

1 Laboratorio de Microbiología Ultraestructural y Molecular, Centro Integral de Microscopía Electrónica (CIME), Facultad de Agronomía y Zootecnia, UNT y CONICET, San Miguel de Tucumán, Tucumán, Argentina

2 Laboratorio de Investigaciones Microbiológicas de Lagunas Andinas (LIMLA), Planta Piloto de Procesos Industriales y Microbiológicos (PROIMI), CCT, CONICET, San Miguel de Tucumán, Tucumán, Argentina

3 HERITAS-CONICET, Ocampo 210 bis, Predio CCT, 2000 Rosario, Santa Fe, Argentina

4 Facultad de Ciencias Naturales e Instituto Miguel Lillo, Universidad Nacional de Tucumán, San Miguel de Tucumán, Tucumán, Argentina

5 Centro Integral de Microscopía Electrónica (CIME, CONICET, UNT), Camino de Sirga s/n. FAZ, Finca El Manantial, 4107 Yerba Buena, Tucumán, Argentina

\section{Introduction}

Central-Andean Ecosystems [between 2000 and $6000 \mathrm{~m}$ above sea level (masl)] are environments suffering from the highest total solar and ultraviolet-B (UV-B) radiation on the planet; a wide daily-temperature range; high salinity (up to $30 \%$ ); scarce nutrient availability; and high concentration of heavy metals and metalloids, especially arsenic (Albarracín et al. 2015, 2016). Andean microbial ecosystems have proven to exhibit an exceptional biodiversity and multiple strategies for enduring such severe conditions (Albarracín et al. 2015, 2016; Solon et al. 2018). Likewise, the utility of exploiting the full potential of polyextremophiles in those ecosystems and the associated extremozymes for biotechnological applications has been widely emphasized (Farias et al. 2011; Albarrac1 and Farías 2012; Bequer Urbano et al. 2013; Albarracín et al. 2014; Ordoñez et al. 2015).

Nesterenkonia is a particular genus belonging to Actinobacteria (Stackebrandt et al. 1995) with most representatives having been isolated from hypersaline or alkaline 
environments such as saline soils, solar salts, seafood, soda lakes, or alkaline wastewater. Some are attractive microbes for possible use in bioprocesses and biotechnological resources (Amiri et al. 2016; Kiran et al. 2017; Prabhakar et al. 2019). In a previous screening for extremophilic Actinobacteria from arid alkaline Puna soil, the dark-yellowpigment strain Nesterenkonia sp. Act20 was identified for the first time (Rasuk et al. 2017). Act20 grew at a high concentration of $\mathrm{NaCl}(25 \%), \mathrm{Na}_{2} \mathrm{CO}_{3}(5 \mathrm{mM})$, and arsenic (up to $200 \mathrm{mM}$ arsenate) and in a wide range of $\mathrm{pH}(5-12)$, with optimal growth at alkaline pHs (Rasuk et al. 2017). In subsequent investigations, our group evidenced that Nesterenkonia sp. Act 20 had a high tolerance to ultraviolet-B (up to $100 \mathrm{~kJ} \mathrm{~m}^{-2}$ ) due to an integrated genomic response to radiation indicated as a UV-resistome (Portero et al. 2019).

The following investigation was aimed at testing the multiresistance of the Act 20 strain by combining phenotypic profiling with an in-depth genomic analysis. In addition, we emphasize the potential for the biotechnological use of extremozymes and extremolytes coded in the strain's genome. The work reported here shed light on the mechanisms underlying microbial adaptation to high-altitude environments, the possible extrapolation of those capabilities for studying other extreme environments of relevance, and the application of these findings to industrial and biotechnologic processes.

\section{Materials and methods}

\section{Strains and culture conditions}

The UV-resistant strain Act20 used in this study was previously isolated from soil around Lake Socompa (3570 masl) at the Andean Puna in Argentina (Rasuk et al. 2017) and belongs to the PROIMI Strain Collection, with P156 being the specific registration number of the strain. Bacterial strain Nesterenkonia halotolerans DSM 15,474 belongs to the DSMZ Bacterial Culture Collection and was used as a control following previous publications (Rasuk et al. 2017). Both strains were grown in an " $\mathrm{H}$ " medium (a medium modified for halophiles, containing $\mathrm{NaCl} 15 \mathrm{~g} \mathrm{~L}^{-1}, \mathrm{KCl} 3 \mathrm{gL}^{-1}$, $\mathrm{MgSO}_{4} 5 \mathrm{gL}^{-1}$, sodium citrate $3 \mathrm{~g} \mathrm{~L}^{-1}$ ) with $2 \%(\mathrm{w} / \mathrm{v})$ agar added when applicable.

\section{Multiresistance assays}

The resistance of strain Act 20 cells to diverse physical and chemical stresses was tested by exposure to desiccation, increasing concentrations of copper, and high UV doses. For studying the response to desiccation, cells were first grown aerobically at $30^{\circ} \mathrm{C}$ overnight in $10-\mathrm{mL}$ of a nutrient-broth medium on a rotary shaker. The cells were then harvested, washed once with sterile $\mathrm{NaCl}$ solution $(0.85 \%$, $\mathrm{w} / \mathrm{v})$, and resuspended to an $\mathrm{OD}_{600 \mathrm{~nm}}$ of $2( \pm 0.1)$ in $\mathrm{NaCl}$ solution. Approximately 20 aliquots $(100 \mu \mathrm{L}$ each) from this cell suspension were spotted onto $0.45-\mu \mathrm{m}$ filters (Sartorius, Göttingen, Germany). These filters were placed onto agar-medium $\mathrm{H}$ plates and incubated at $30^{\circ} \mathrm{C}$ for 5 days. The colonies were then left to dry by incubation in empty sterile dishes at $25^{\circ} \mathrm{C}$ and $18 \%$ relative humidity for 50 days. The viable-cell count in colony-forming units (CFU) was assessed at different times. The filters on which the strains had grown were added to sterile microcentrifuge tubes. The cells from each filter were resuspended separately, and the CFU determined before and after desiccation. The tolerance to desiccation was determined in Act 20 with $N$. halotolerans DSM 15,474 as a control.

Resistance to UV irradiation and copper salts was tested by a quick qualitative method. For assaying the copper-resistance profile, aliquots of $5 \mu \mathrm{L}$ of an overnight $\left(\mathrm{OD}_{600} \approx 0.6\right)$ culture were loaded onto $\mathrm{H}$-medium agar plates supplemented with 1,2 , or $3 \mathrm{mM} \mathrm{CuSO}_{4}$. The control cultures consisted of an " $\mathrm{H}$ " medium without copper supplementation. They were then incubated for $72 \mathrm{~h}$ at $30^{\circ} \mathrm{C}$ under continuous photosynthetically-active radiation luminosity with an OSRAM 100-W lamp.

For the UV-resistance assays, the cells were precultured in liquid medium $\mathrm{H}$, and upon reaching an $\mathrm{OD}_{600 \mathrm{~nm}}=0.6$ collected for serial dilutions. Aliquots of $5 \mu \mathrm{L}$ were then loaded onto agar-medium plates and immediately exposed to UV-B irradiation (Vilbert Lourmat VL-4, the maximum intensity at $312 \mathrm{~nm}$ ) for $5 \mathrm{~min}$ at $1.7 \mathrm{Kj} \mathrm{m}^{-2}, 15 \mathrm{~min}$ at 5.1 $\mathrm{Kj} \mathrm{m}^{-2}$ ), and $30 \mathrm{~min}$ at $10.4 \mathrm{Kj} \mathrm{m}^{-2}$ ). They were next incubated for $72 \mathrm{~h}$ at $30^{\circ} \mathrm{C}$ in the dark to prevent photoreactivation. UV-B irradiance was quantified with a radiometer (Vilbert Lourmat model VLX-3 W) coupled with a UV-B sensor (Vilbert Lourmat model CX-312). The minimal intensity measured was $5.21 \mathrm{~W} \mathrm{~m}^{-2}$, and the maximal power $5.4 \mathrm{~W} \mathrm{~m}^{-2}$. Controls of unexposed samples were run simultaneously in the dark.

Microbial growth was recorded with three plus signs $(+++)$ when similar to the growth in controls, two $(++)$ when the growth was slightly different from the growth in the controls, one sign (1 pts) when growth was low (with only isolated colonies), and no sign when no growth occurred at all. Parallel assays were performed for $N$. halotolerans DSMZ 15,474 to compare the two resistance profiles.

\section{Microscopical observation and ultrastructural characterization of Act 20 cells}

Assays were designed to evaluate the morphology and ultrastructure of Act20 under challenging conditions similar to those present in their original environment-i.e., under high UV irradiation and chemical (copper) stress. 
The selected strains were grown in $\mathrm{H}$ medium at $30^{\circ} \mathrm{C}$ with shaking $(180 \mathrm{rpm})$. Cells in the mid-log phase of growth were harvested by centrifugation $(5000 \mathrm{rpm}$ for $10 \mathrm{~min}$ ). The pellets were washed twice in $0.9 \%(\mathrm{w} / \mathrm{v})$ $\mathrm{NaCl}$ and then kept under starvation conditions for $18 \mathrm{~h}$ at $4{ }^{\circ} \mathrm{C}$ in the same solution. Of this cell suspension, $20 \mathrm{~mL}$ were transferred to a sterile plate and exposed to UV-B irradiation at different times, as indicated above. The copper-challenged cultures were likewise obtained by growing the cells in $\mathrm{H}$ medium with and without $3 \mathrm{mM} \mathrm{Cu}$.

For scanning electron microscopy (SEM) and transmission electron microscopy (TEM), $100 \mu \mathrm{L}$ aliquots were collected for each treatment and centrifuged $(5000 \mathrm{rpm}$ for $10 \mathrm{~min}$ ) to remove the supernatant. The pellets were immediately fixed with Karnovsky's fixative [a mixture of $2.66 \%(\mathrm{v} / \mathrm{v})$ paraformaldehyde and $166 \%(\mathrm{v} / \mathrm{v})$ glutaraldehyde] in a $0.1 \mathrm{M}$ phosphate buffer $\mathrm{pH} 7.3$, for $48 \mathrm{~h}$ at $4{ }^{\circ} \mathrm{C}$. For SEM, the cells were processed according to previously optimized methods (Zannier et al. 2019). The procedure stated in brief, aliquots of $50 \mu \mathrm{L}$ of fixed samples were placed on coverslips for electron microscopy and kept for $3 \mathrm{~h}$ at room temperature. The samples were then dehydrated in graded ethanol $(30 \%, 50 \%, 70 \%, 90 \%$, and $100 \%$ ) for 10 min each and finally maintained in $100 \%$ acetone for $40 \mathrm{~min}$. The dehydration was completed by reaching the critical drying point (Denton Vacuum model DCP-1), in which acetone was exchanged by liquid $\mathrm{CO}_{2}$. The samples were then mounted on stubs and covered with gold (Ion Sputter Marca JEOL model JFC-1100) for observation under a Zeiss Supra 55VP (Carl Zeiss NTS GmbH, Germany) SEM belonging to the Electron Microscopy Core Facility (CIME). For TEM, the protocol from Albarracín et al. (2008) was followed. After fixation, the samples were washed twice by centrifuging in $0.1 \mathrm{M}$ phosphate buffer, pH 7.3 (@x $g$ for $10 \mathrm{~min}$ ), and embedded in agar (Bozzola 2007). The agar pellets were postfixed in $1 \%(\mathrm{w} / \mathrm{v})$ osmium tetroxide in phosphate buffer, pH 7.3, overnight at $4{ }^{\circ} \mathrm{C}$. After washing with the same buffer, the samples were stained in $2 \%(\mathrm{w} / \mathrm{v})$ uranyl acetate solution for $30 \mathrm{~min}$ at room temperature, then dehydrated with ethanol solutions of increasing concentrations $(70 \%, 90 \%$, and $100 \%)$ for $15 \mathrm{~min}$ each, and finally maintained in $100 \%$ acetone for $30 \mathrm{~min}$. Next, the infiltration and embedding in an acetone-SPURR-resin sequence was carried out, followed by polymerization at $60^{\circ} \mathrm{C}$ for $24 \mathrm{~h}$. Ultrathin sections were cut with a diamond knife on a manual ultramicrotome (Sorvall Porter-Blum Ultramicrotome MT-1). The bacteria were examined under a Zeiss LIBRA 120 (Carl Zeiss AG, Alemania) transmission electron microscope belonging to the Electron Microscopy Core Facility (CIME-CONICET-UNT) at $80 \mathrm{kV}$.

\section{Genome sequencing, assembly, and gap closure}

Genomic DNA from Nesterenkonia sp. Act20 strain was purified from cells grown on LB broth for $72 \mathrm{~h}$ at $30^{\circ} \mathrm{C}$ and harvested by centrifugation $\left(3000 \times g\right.$ for $10 \mathrm{~min}$ at $\left.4{ }^{\circ} \mathrm{C}\right)$. The pellets were washed twice with distilled water by centrifuging. We extracted the total genomic DNA with the DNeasy Blood and Tissue Kit (Qiagen) following the manufacturer's recommendations. We perfomed whole-genome shotgun pyrosequencing using a 454-preparation kit (Roche Applied Sciences, Indianapolis, IN, USA) and sequenced with a GS-FLX ${ }^{\mathrm{TM}}$ genome sequencer using Titanium chemistry (454 Life Sciences, Roche Applied Sciences). The 454 reads were assembled with Newbler Assembler software, v. 2.5.3, with-URT option. Extra-assembling programs were run: MIRA v. 3.4.0 and Celera Assembler, v. 6.1. The different assemblages were fused through the use of a MINIMUS 2 Pipeline from the AMOS Package. The merged assembly was used as a guide for designing the primers, which were, in turn, used to confirm contig joints and close gaps. The overall sequence coverage was 37X; This Whole Genome Shotgun project has been deposited at DDBJ/ENA/GenBank under the accession sequece JADPQH000000000. The version described in this paper is version JADPQH010000000.

\section{Genome analysis}

Genome annotation was implemented by means of PROKKA (Seemann 2014) with a custom expanded protein database, which includes Swiss-Prot, TrEMBL, Pfam, SUPERFAMILY, TIGRFAM, and a genus-specific database built from GenBank files downloaded from the database of the National Center for Biotechnology Information (NCBI). We processed the set of annotated FASTA files belonging to genomes with Proteinortho, which program detects orthologous genes within different species. For doing so, the software compares similarities of given gene sequences and clusters the former to find significant groups (Lechner et al. 2011).

\section{Phylogenetic analysis}

The sequence-based taxonomic analysis was performed by means of both 16 S-rDNA and whole-genome comparisons. The sequences from genomes and 16 S-rDNA, whose characteristics are summarized in Supplementary Table S1, were obtained from the NCBI database (Assembly and RefSeq). Certain 16 S-rDNAs were retrieved from genome sequences to link both types of analysis. The sequences from 16 S-rDNA were aligned with Silva Incremental Aligner (Pruesse et al. 2012) and the phylogenetic tree created with Fasttree 2.1.7 (Price et al. 2010) and the Maximum Likelihood method through the use of the Generalized 
Time-Reversible (GTR) model. The subsequent processing and visualization of the tree were performed with iTOL (Letunic and Bork 2016). Genome-wide nucleotide-identity patterns were explored in the genome dataset by estimating all-against-all pairwise average nucleotide identity (ANI). We utilized the ANIm approach that uses MUMmer (NUCmer) to align the input sequences as implemented in pyANI (Kurtz et al. 2004). The average between any given pair was used as the final value. Heatmaps were generated by the heatmap V 1.0.12 R software package.

\section{Results}

\section{Taxonomic affiliation of Nesterenkonia sp. Act20}

Nesterenkonia sp. Act 20 was first isolated by Rasuk et al. (2017) and initially assigned to the genus by partial $16 \mathrm{~S}-\mathrm{rDNA}$ sequencing. The present work compared the full 16 S-rDNA sequence from Act20 with related strains, resulting in a $98.2 \%$ identity with $N$. sandarakina YIM 70,009 and a $97.4 \%$ identity with both $N$. jeotgali JG-241 and $N$. halotolerans YIM70084. The phylogenetic tree based on this marker also suggested a close relationship of Act20 with the above three plus $N$. sp. AN1, $N$. aurantiaca strains, $N$. sandarakina, and N. Lutea; with those all clustering together in a statistically significant clade (Fig. 1A). The wholegenome analysis by the ANI method revealed a similar relationship pattern (Fig. 1B). In this analysis, $N$. sp. Act 20, $N$. aurantiaca DSM 27,373, $N$. sp. AN1, $N$. jeotgali CD087, and $N$. sandarakina CG 35 clustered significantly; and Act20 had a lower percent average nucleotide difference (defined as 100\%-ANI) than the proposed $95 \%$ threshold (Richter and Rosselló-Móra 2009), suggesting that that strain could be of a novel species.

\section{Multiresistance profile of Act20}

Resistance to desiccation, UV, and copper was demonstrated in $N$. sp. Act 20 and compared with the closest relative, $N$. halotolerans $(\mathrm{NH})$. Table 1 summarizes this multiresistance. The tolerance to desiccation was tested every seven days for seven weeks. Act 20 maintained its population in the same order of magnitude for 14 days, but from the 3rd week on, exhibited no development whatsoever (Fig. S1). The NH population, for its part, decreased by one order of magnitude

Table 1 Multiresistance profile of Act20 strain and comparison with $\mathrm{NH}$

\begin{tabular}{lll}
\hline & Act20 & $\mathrm{NH}$ \\
\hline Desiccation period (days) & & \\
7 & +++ & + \\
14 & ++ & + \\
21 & - & - \\
Copper concentration $(\mathrm{mM})$ & & \\
1 & +++ & +++ \\
2 & ++ & ++ \\
3 & + & + \\
$\mathrm{UV}$ dose $\left(\mathrm{Kj} \mathrm{m}^{-2}\right)$ & & ++ \\
1.7 & +++ & + \\
5.1 & ++ & + \\
10.4 & + & + \\
\hline
\end{tabular}

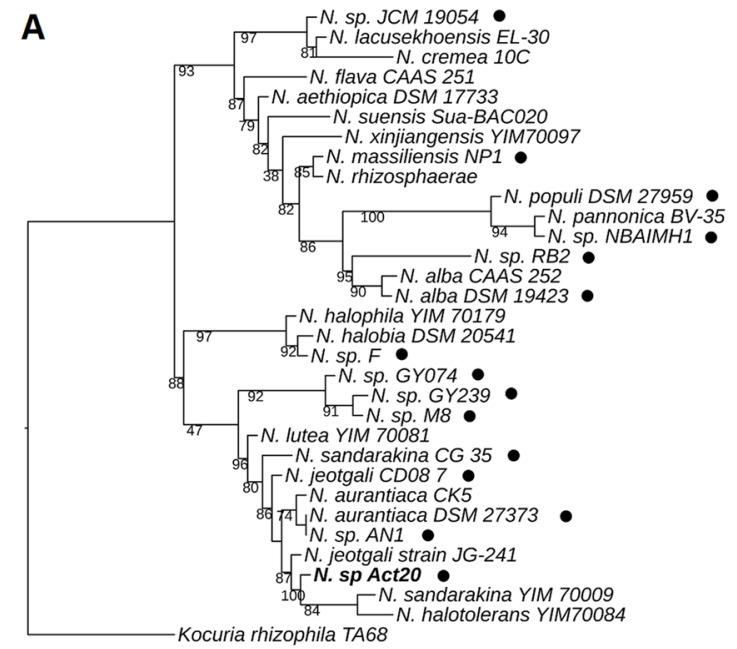

Fig. 1 Phylogenetic nearest-neighbor analysis of Nesterenkonia strains. Strain $N$. sp. Act20 is indicated in boldface throughout. A Maximum likelihood tree from the similarities of 16 S-rRNA-gene sequences. The black dots denote the retrieval of the gene from a

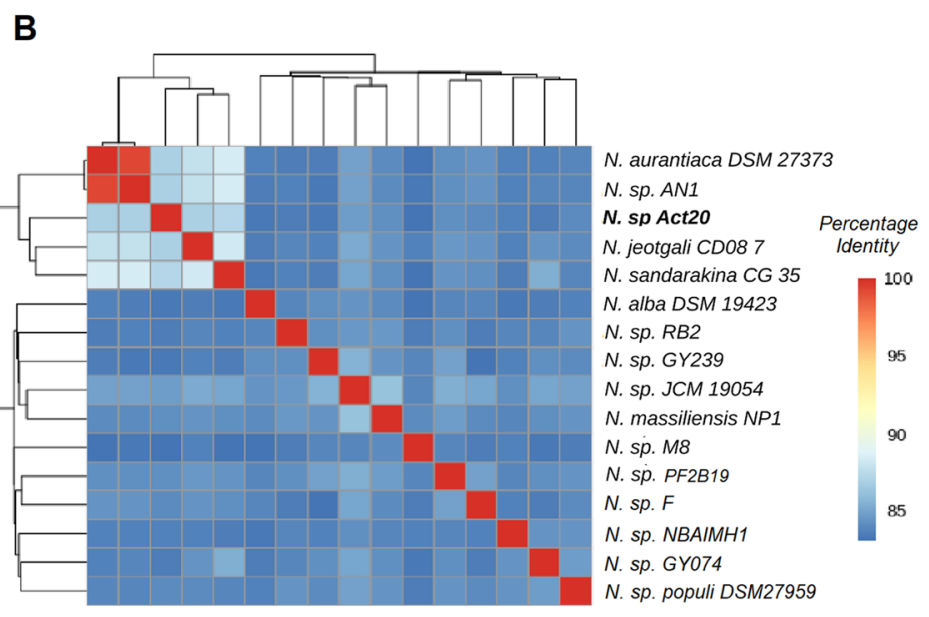

sequenced genome. B Heatmap based on the average nucleotide identity of the whole genome. Act20 is distinct and inside the significant cluster 
after 7 and 14 days of treatment and then did not survive beyond 14 days of continuous drying.

With respect to tolerance to UV radiation, our results indicated that Act 20 was much more resistant than the selected control strain (Fig. S2), growing even after a dose of $10.4 \mathrm{Kj} \mathrm{m}^{-2}$ of UV-B radiation. Likewise, the copperresistance profile was similarly high for both strains, with Act 20 and $\mathrm{NH}$ developing quite well even at the maximum concentration tested $(3 \mathrm{mM})$.

\section{General genomic features}

The assembly process led to two scaffolds: the larger at $2,092,188$ bp in length and a $\mathrm{G}+\mathrm{C}$ content of $65.98 \%$, and the smaller at 836,993 bp and a $\mathrm{G}+\mathrm{C}$ content of $65.82 \%$. The entire genome of $N$. sp Act20 consists of 2,930,097 bp at a GC content of $65.9 \%$. PROKKA annotation detected 2672 coding sequences, including 2377 annotated genes and 58 RNAs. The Act 20 genomic features were compared to those of another fifteen Nesterenkonia genomes available in the NCBI assembly database (Table S6). Supplementary Table S2 lists the annotated genes of Act20, their sequence length, and the genetic functions assigned by homology along with the KO identifiers linked for some of those genes. Tables S3 and S4. summarize the most relevant annotated functions.

\section{Genomic traits of the Act20 multiresistance phenotype}

The genome encoded pathways associated with osmotic, oxidative-stress, and starvation responses and low-temperature and low-oxygen conditions along with traits related to resistance to heavy metals (mainly copper and mercury), antibiotics (mainly beta-lactams and vancomycin), arsenic, fluoride, and chlorite (Tables S3, S4).

Both, the Prokka and RAST annotations account for several genes for resistance and/or tolerance to copper (Table 2). Among the direct mechanisms of copper resilience in Act 20 described by Giachino and Waldron (2020) are the cop family, implicated in copper homeostasis through the capture and expulsion of $\mathrm{Cu}[\mathrm{I}]$ ions from the cytosol into the periplasm. This mechanism may be complemented by the action of a copper oxidase necessary for converting $\mathrm{Cu}[\mathrm{I}]$ to $\mathrm{Cu}[\mathrm{II}]$, which is more biologically inert and tends to remain in the periplasm. Of interest to us was the presence of a gene related to a recently discovered family of copper-binding proteins involved in cytosolic copper storage (Dennison et al. 2018). In contrast, the indirect mechanisms would involve the participation of genes whose actions compensate for specific damage caused by toxic copper. Such is the situation with the specific DsbD oxidase that rearranges misfolded peptides and the Fur master regulator of iron metabolism that counteracts

Table 2 Group of genes potentially involved in the copper resistance reported for Act20

\begin{tabular}{|c|c|}
\hline Copper tolerance/resistance trait & Function \\
\hline Copper-translocating P-type ATPase & $\begin{array}{l}\text { Probably similar to P-type ATPase CopA, an essential efflux pump that actively } \\
\text { secretes } \mathrm{Cu}(\mathrm{I}) \text { from the cytoplasm to the periplasm, maintaining the copper } \\
\text { homeostasis (Giachino and Waldron 2020) }\end{array}$ \\
\hline CopC domain protein & $\begin{array}{l}\text { CopC is a bacterial blue copper protein that binds } 1 \text { atom of copper per protein } \\
\text { molecule. Along with CopA, CopC mediates copper resistance by sequestra- } \\
\text { tion of copper in the periplasm (Arnesano et al. 2003) }\end{array}$ \\
\hline Putative CopD protein & $\begin{array}{l}\text { Exact function is not known. Protein is involved in copper resistance and appears } \\
\text { to be involved in copper uptake in conjunction with CopC (Swiss-Prot) }\end{array}$ \\
\hline CopZ & $\begin{array}{l}\text { Chaperone that serves for the intracellular sequestration and transport of toxic } \\
\text { copper from the cytosol to the periplasm (Giachino and Waldron 2020) }\end{array}$ \\
\hline Copper oxidase & $\begin{array}{l}\text { Probably a periplasmic copper oxidase-like } \mathrm{CueO} \text {, which reduces the } \mathrm{Cu}(\mathrm{I}) \text { flux } \\
\text { to the cytosol by converting periplasmic } \mathrm{Cu}(\mathrm{I}) \text { to } \mathrm{Cu}(\mathrm{II}) . \mathrm{Cu}(\mathrm{II}) \text { is more bio- } \\
\text { logically inert, making it a relatively "safe" species for cells compared to } \mathrm{Cu}(\mathrm{I}) \\
\text { (Giachino and Waldron } 2020 \text { ) }\end{array}$ \\
\hline DsbD domain-containing protein & $\begin{array}{l}\text { DsbD (aka CutA) oxidoreductase rearranges the misfolded peptides when incor- } \\
\text { rect disulfide bonds are inserted by toxic copper (Giachino and Waldron 2020) }\end{array}$ \\
\hline Four-helix bundle copper-binding protein & $\begin{array}{l}\mathrm{Cu}(\mathrm{I}) \text { cytosolic storage protein, first found in methanotrophic bacteria, which use } \\
\text { large amounts of copper to metabolize methane. Its function in other bacteria } \\
\text { regarding what they are storing copper for remains unknown (Dennison et al. } \\
\text { 2018) }\end{array}$ \\
\hline Fur family ferric uptake transcriptional regulator & $\begin{array}{l}\text { As toxic copper provokes mismetalation of iron metalloenzymes, Fur master } \\
\text { regulator of iron metabolism is overexpressed under copper stress and is } \\
\text { required for copper resistance even at low copper concentrations (Giachino and } \\
\text { Waldron 2020) }\end{array}$ \\
\hline
\end{tabular}


the constant scavenging of iron cofactors from enzymes, which reduction in turn can generate reactive oxygen species (Giachino and Waldron 2020).

Previous assays carried out on Act20 (Rasuk et al. 2017) revealed the actinobacterium's ability to grow in alkaline media (up to $\mathrm{pH} 12$ ) and at high concentrations of $\mathrm{NaCl}$ $(25 \%)$ and $\mathrm{Na}_{2} \mathrm{CO}_{3}(5 \mathrm{mM})$. In the present work, we also verified the strain's desiccation tolerance, a phenotype that is supported by a vast repertory of genes (Table 3). This ability may be explained by the presence of transporters for the uptake of a diverse organic osmoprotectants such as glycine betaine, proline betaine, glycerol, choline, and trehalose. Genes for the synthesis of glycine betaine and the complete set of genes for ectoine were also detected (Table 3, Fig. S3). These compounds counteract the environment's high osmolality avoiding a rapid efflux of water from the cell and, consequently, the loss of turgor (Wood 1988; Styrvold and Strom 1991; Lucht and Bremer 1994; Nagata and Wang 2001). Additional genes conferring environmental protection, like OsmC and MdoB, are involved in coping the osmotic stress in other ways (Atichartpongkul et al. 2001) —in particular, the MdoB locus, whose product utilizes the periplasm and the outer membrane to facilitate its effect (Sleator and Hill 2002), with neither structure being present in Gram-positive bacteria including Act20.
Genes for the metabolism of arsenic, a toxic element that can limit or suppress bacterial growth, was also detectable in Act20's genome. That Act 20 can tolerate arsenic in the form of As [V] at 0-200 $\mathrm{mM}$ had been previously demonstrated (Rasuk et al. 2017). In the present work, we detected the presence of an arsenate reductase (not specified), an arsenate-mycothiol transferase, an arsenic transporter (not specified), and seven regulators of the ArsR family (Table S3).

The genomic profile of the ATP-binding-cassette transporters, the so-called $A B C$ transporters, and the two-component system-it sensing specific environmental stimuli in tandem with a cognate regulator-is also a reflection of the original environment. The set of encoded proteins to sense phosphate limitation in conjunction with subsequent phosphorus incorporation (in the form of phosphates and phosphonates) is evident (Figs. S4, S5). A similar form of regulation for adaptation is noted for osmotic stress. Other environmental-sensing systems are directed at oxygen limitation, low temperature, cell-envelope and cell-wall stress, and antibiotics. Transporters for iron and various organic compounds such as carbohydrates (mostly of plant origin), nucleosides, amino acids, and oligopeptides were also reported.

To discover the unique functional traits of Act20, we searched the orthologous sequences for publicly available

Table 3 Group of genes potentially involved in the desiccation resistance reported for Act20

\begin{tabular}{|c|c|}
\hline Desiccation tolerance/resistance trait & Function \\
\hline SugA-SugB-SugC & $\begin{array}{l}\text { ABC transporter complex specific for the uptake of trehalose (osmoprotectant). Involved } \\
\text { in the recycling of extracellular trehalose released from trehalose-containing molecules } \\
\text { (Kalscheuer et al. 2010) }\end{array}$ \\
\hline Trehalase & $\begin{array}{l}\text { Trehalose degradation. It may be necessary for controlling the levels of intracellular } \\
\text { trehalose (Carroll et al. 2007) }\end{array}$ \\
\hline OpuBC-OpuBB-OpuBA & $\begin{array}{l}\text { High-affinity multicomponent binding-protein-dependent transport system for the osmo- } \\
\text { protectant choline (Kappes et al. 1999) }\end{array}$ \\
\hline ProX-ProW-ProV & $\begin{array}{l}\text { ABC transporter complex involved in the uptake of osmoprotectants glycine betaine and } \\
\text { proline betaine (Gul and Poolman 2013) }\end{array}$ \\
\hline Choline dehydrogenase & Involved in the biosynthesis of the osmoprotectant glycine betaine (Boch et al. 1996) \\
\hline Betaine-aldehyde dehydrogenase & $\begin{array}{l}\text { Involved in the biosynthesis of the osmoprotectant glycine betaine. Catalyzes the revers- } \\
\text { ible oxidation of betaine aldehyde to the corresponding acid (Boch et al. 1997) }\end{array}$ \\
\hline HTH-type transcriptional regulator BetI & $\begin{array}{l}\text { Repressor involved in the biosynthesis of the osmoprotectant glycine betaine. It represses } \\
\text { transcription of the choline transporter BetT and the genes of BetAB involved in the } \\
\text { synthesis of glycine betaine (Lamark et al. 1996) }\end{array}$ \\
\hline EctA-EctB-EctC-EctD & $\begin{array}{l}\text { Group of genes involved in the biosynthesis of the osmoprotectant ectoine (Reshetnikov } \\
\text { et al. 2006) }\end{array}$ \\
\hline Glycerol uptake facilitator protein & $\begin{array}{l}\text { Transporter of the osmoprotectant glycerol across the cytoplasmic membrane (Hénin } \\
\text { et al. 2008) }\end{array}$ \\
\hline Phosphoglycerol transferase I MdoB & $\begin{array}{l}\text { Participate in anionic-polymer biosynthesis (containing between six and } 12 \text { glucose units } \\
\text { with an average charge of -5). These polymers generate a Donnan potential across the } \\
\text { outer membrane, resulting in the accumulation of cations to a higher concentration in } \\
\text { the periplasm than in the medium, consequently giving rise to hydrostatic pressure in } \\
\text { the periplasmic space (Sleator and Hill 2002) }\end{array}$ \\
\hline OsmC & $\begin{array}{l}\text { The osmotically inducible expression of the gene suggests that it could have some kind of } \\
\text { role in the bacterial osmotic-stress response (Atichartpongkul et al. 2001) }\end{array}$ \\
\hline
\end{tabular}


Nesterenkonia genomes. The set of annotated FASTA files belonging to genomes were processed through Proteinortho, which software detects orthologous genes within different species. The proteins of Act 20 that did not match any ortholog were analyzed one by one to verify if the annotated function they encoded was unique to Act20 in not being present in other representatives of the genera. Table 4 lists the exclusive traits of Act20, with most being related to its extreme natural environments such as bacterial persistence; bacterial cell-envelope-stress response; and resistance to osmotic stress, desiccation, and phosphate starvation. The degradative enzymes 6-deoxy-6-sulfogluconolactonase and $\alpha$-xylosidase take part in the decomposition of prototrophic biomass present in the soil, which material Act 20 could utilize. The remaining functions were characterized only at the protein-domain level, like ethyl-t-butyl-ether degradation, second-messenger sensors, and cell-wall binding.

\section{UV-resistome of Act20}

The high UV-resistance profile of Act 20 calls for a more in-depth characterization and points to the existence of coordinated physiologic and molecular mechanisms triggered by ultraviolet-light exposure. This system was previously named UV-resistome and was described for other polyextremophiles of the Andean microbial ecosystems (Kurth et al.
2015; Portero et al. 2019). Ideally, the UV-resistome depends on the expressiion of a diverse set of genes devoted to evading or repairing the damage provoked directly or indirectly by UV light. Ideally, the overall resistome encompasses the following subsystems: (1) UV-sensing and effective response regulators, (2) avoidance and shielding strategies, (3) damage-tolerance and oxidative-stress responses, and (4) DNAdamage repair. Therefore, we screened genes associated with each of these UV-B-resistome subsystems for all available genomes of the Nesterenkonia genus. This approach revealed Act20's relative genomic potential of for defending itself from UV-B radiation, thus constituting a strain that naturally endures the highest irradiation on the planet. Unlike the approach in previous investigations, we studied the UVresistance comprehensively, including genes that could have the potential to generate an UV-evasion response or could lessen the negative impact of the light - such as motility genes, pilus, and gas vesicles (Damerval et al. 1991).

Table S5 details the UV-resistome for every strain and clusters that system by subsystems. The collections summarized all types of damage repair, homologous or direct, of base or nucleotide excisions or mismatches via translesion-DNA-synthesis factors and SOS-response factors plus explicit mechanisms for an oxidative-stress response and for UV avoidance and/or protection-i.e., the synthesis of photoprotective pigments and genes for flagellum, pilus,

Table 4 New functional traits (with no counterpart in other Nesterenkonia) of Nesterenkonia sp. Act 20 revealed by genome functional annotation and ortholog clustering

\begin{tabular}{|c|c|}
\hline Unique trait & Function \\
\hline Protein SphX & $\begin{array}{l}\text { High-affinity phosphate-binding protein induced by phosphate starvation. } \\
\text { (Harke and Gobler 2013) }\end{array}$ \\
\hline Serine/threonine-protein kinase toxin HipA & $\begin{array}{l}\text { Toxin that induces bacterial persistence and multidrug resistance (Kaspy } \\
\text { et al. 2013) }\end{array}$ \\
\hline 6-Deoxy-6-sulfogluconolactonase & Sulfoquinovose degradation (Felux et al. 2015) \\
\hline Trehalase & Trehalose degradation (Carroll et al. 2007) \\
\hline a-xylosidase & $\begin{array}{l}\text { Catalyzes the liberation of alpha-xylose from the nonreducing terminal } \\
\text { glucose of xyloglucan oligosaccharides (Matsuzawa et al. 2016) }\end{array}$ \\
\hline 4-Deoxy-L-threo-5-hexosulose-uronate ketol-isomerase & $\begin{array}{l}\text { Plays a role in the catabolism of hexuronates under osmotic stress condi- } \\
\text { tions, likely substituting for the regular hexuronate-degrading enzyme } \\
\text { UxaC whose expression is repressed in these conditions (Rothe et al. } \\
\text { 2013) }\end{array}$ \\
\hline Pleckstrin homology domain (bPH_1) & $\begin{array}{l}\text { Appears to be involved in the bacterial-cell-envelope-stress response (Xu } \\
\text { et al. 2010) }\end{array}$ \\
\hline $\begin{array}{l}\text { SMODS-associated and fused to various effectors sensor (SAVED) } \\
\text { domain }\end{array}$ & $\begin{array}{l}\text { Senses nucleotide or nucleotide derivatives second messengers and } \\
\text { activates effectors deployed by a class of conflict systems that rely on } \\
\text { the production and sensing of the nucleotide second messengers (Bur- } \\
\text { roughs et al. 2015) }\end{array}$ \\
\hline WxL domain & $\begin{array}{l}\text { Cell-wall binding in gram-positive bacteria, and may interact with the } \\
\text { peptidoglycan (Brinster et al. 2007) }\end{array}$ \\
\hline EthD domain & $\begin{array}{l}\text { Related to the EthD protein, which is involved in the degradation of ethyl } \\
\text { tert-butyl ether (Chauvaux et al. 2001) }\end{array}$ \\
\hline Coronavirus endopeptidase C 30 & $\begin{array}{l}\text { Involved in viral polyprotein processing in replication (Ziebuhr et al. } \\
2000 \text { ) }\end{array}$ \\
\hline
\end{tabular}


gas vesicles, and swarming motility (Fig. 2). The horizontal bars of the figure are sorted from top to bottom, in accordance with the number of different genes for each subsystem. Act 20 is positioned at the top with the most diverse and complete UV-resistome, containing 114 genes, followed by NBAIMH1 with 107 genes, which strain also belongs to an extreme-altitude environment. Of particular interest to us was that, other strains from harsh environments with expected high solar radiation, such as AN1 and M8 with 85 and 83 genes, respectively, also have robust UV-resistomes. In contrast, strains belonging to environments with little or null exposure to solar radiation present fewer and less diverse genes-i.e., N. alba. DSM19423, GY074, and RB2 with 56,63 , and 65 genes, respectively.

\section{Ultrastructural changes in UV-challenged Act20 cells}

The morphology and ultrastructure of the actinobacterium $N$. sp. Act20 was observed under UV-challenging and nonchallenging conditions to determine their behavior in their original environment. $\mathrm{NH}$ was used for comparison., Under normal conditions, Act20 and DSM 15,474 cells appeared under SEM as irregular coccoids or short and rod-shaped. Their dimensions varied between 0.41 and $0.43 \times 0.6-0.82 \mu \mathrm{m}$ for Act20 and $0.41-0.38 \times 0.71-0.51$ for $\mathrm{NH}$. The exterior surface was smooth without evidence of cell wall rupture (Fig. 3A, E). In contrast, after exposure to UV both strains exhibited morphologic alterations, and those were consistently more severe in $\mathrm{NH}$ cells.

As the dose increased, the Act20 morphology changed with the individuals becoming longer and sometimes wider, due to an interruption of cell division that caused a complete deformation in the cell (cf. the black arrows in Fig. 3C, D). Furthermore, the surface of the cells appeared with signs of shrinkage (cf. white arrows in Fig. 3C). In NH, fibrillar structures were observed only on the surface of cells treated for 5 and 15 min with UV radiation (Fig. 3F, G). We found that, at the dose of $0.51 \mathrm{Jls} \mathrm{cm}^{-2}$ (15 min), the pili thickened, and in some sections, broke or disintegrated (cf. Fig. 3G, white arrows). At 30 min of exposure (Fig. 3H), cell aggregates were observed in which bacterial cells adhered to one another by self-produced extracellular polymeric substances. A surface irregularity was also observed, indicating the wall-cell rupture and degradation, causing cell lysis (Fig. 3H, black arrow).

TEM images for both strains were likewise obtained (Fig. 4). TEM analysis revealed the typical Gram-positive bacterial structure, involving an intense electron-opaque inner layer corresponding to the cytoplasmic membrane and a less electron-opaque outer layer or cell wall.

Ultrastructural changes were observed in the cells after exposure to UV radiation, especially at the structural-membrane level, acquiring a certain degree of disorganization compared to the untreated strains (controls). A general observation in both UV-treated bacteria was that numerous cells contained septa, compared to control samples. Radiation stress probably caused cell division to stop at this point without completing cell separation, whereas in control cells the division was normal.

Furthermore, variations in the cell-envelope thickness were frequently observed (cf. black arrows in Fig. 4). During the highest doses of UV radiation (15- and

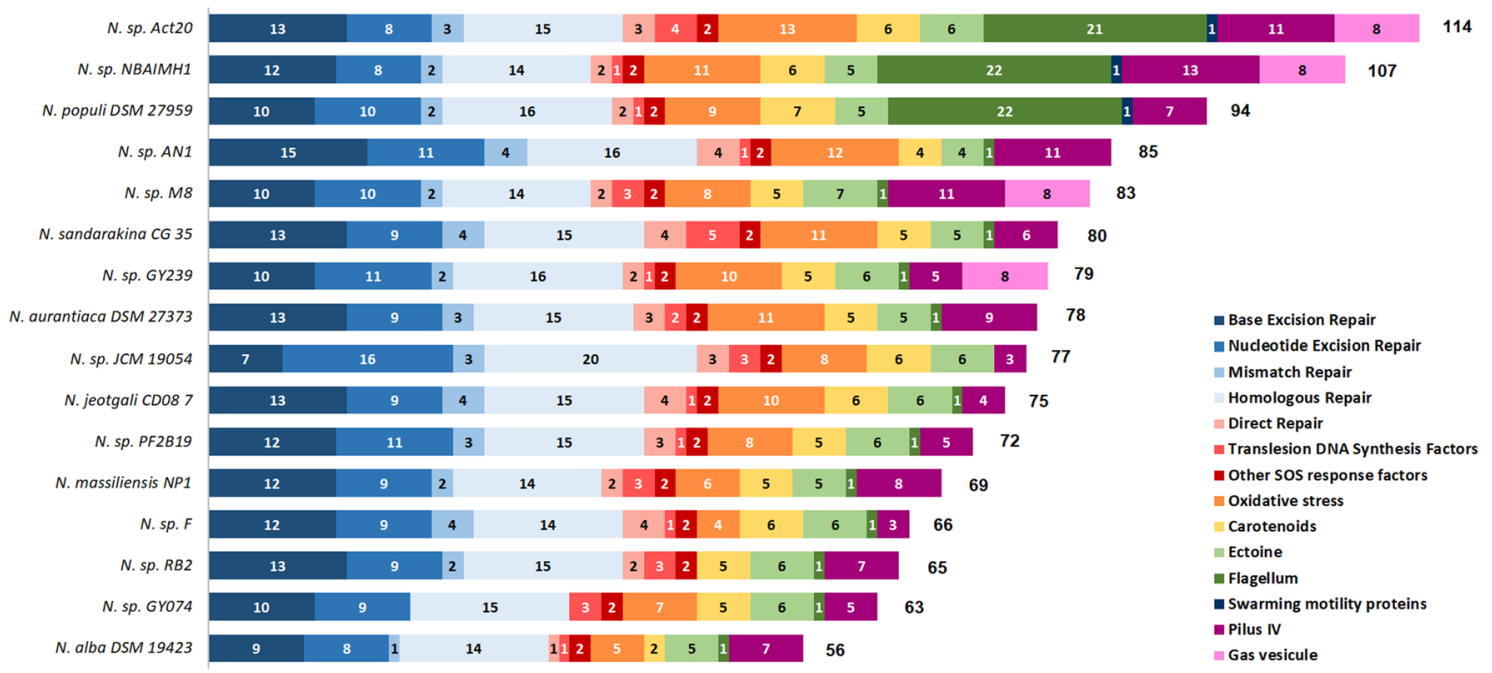

Fig. 2 UV-resistome genotypes of $N$. sp. Act20 and related strains. The stacked horizontal bar chart summarizes the count (numbers inside bar segments) of genes for all the UV-resistome subcategories listed with the corresponding colors in the key to the right, including the totally of those genes at the right end of each bar. Note how the bar widths diminish proceeding from the top (Act20) to the bottom, visually illustrating the progressingly decreasing genetic complexity of the strains below Act 20 


\section{N. sp. Act20}
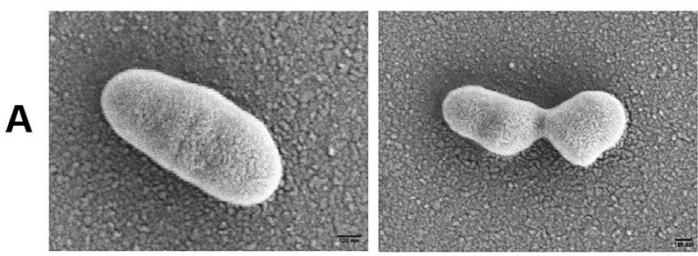

B
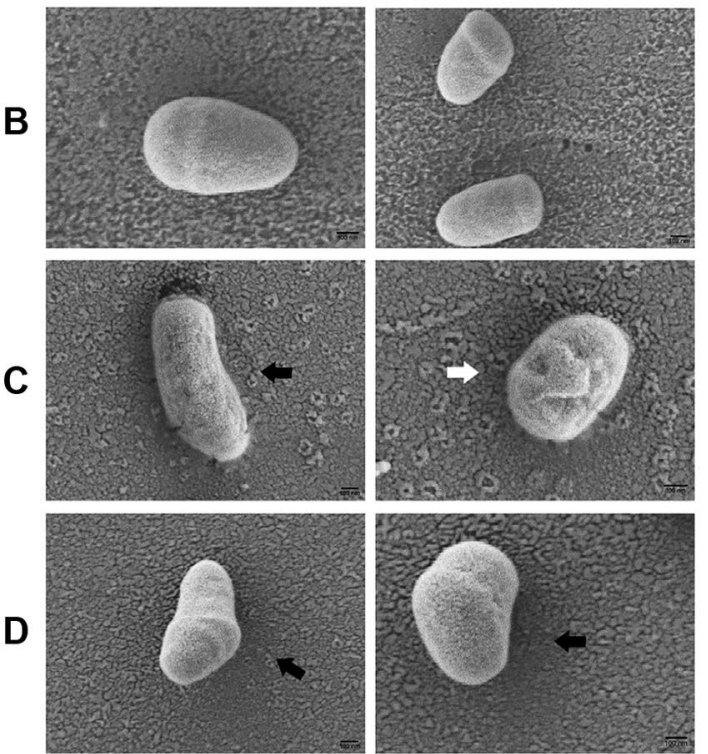

Fig. 3 SEM micrographs of actinobacteria after exposure to UV-B radiation. A-D $N$. sp. Act20. E-H $N$. halotolerans DSM 15,474. A, E Nonexposed growing bacterial cells (control). Growing bacterial cells exposed to $(\mathbf{B}, \mathbf{F}) 0.17 \mathrm{Jls} \mathrm{cm}{ }^{-2}$ of UV-B (5 min). C, G 0.51

30-min exposure), the different cytoplasmic structures were visualized by electron-density variations. In Act20, polyphosphate-like granules were visible, appearing as electron-dense aggregates, scattered throughout the cytoplasm but surrounding the nucleoid, with diameters varying between 0.2 and $0.3 \mu \mathrm{m}$ (Fig. $4 \mathrm{C}, \mathrm{D}$ ), along with mesosome-like structures formed from projections of the cytoplasmic membrane (Fig. 4D). In addition, an interaction between neighboring cells could be observed (cf. white arrows in Fig. 4D). In NH, the damage caused by $\mathrm{UV}$ at the cytoplasmic-membrane level was more pronounced. The heterogeneous and disorderly appearance (cf. gray arrows in Fig. 4G, H) could result from a loss of membrane integrity, leading to a malfunction of the permeability barrier and inducing cell lysis. Mesosomelike structures (Fig. 4G, H) are frequent, and the interaction between bacteria mediated by pili or extracellular polymeric substances is likewise a common feature (cf. white arrows).

\section{N. halotolerans DSM15474}
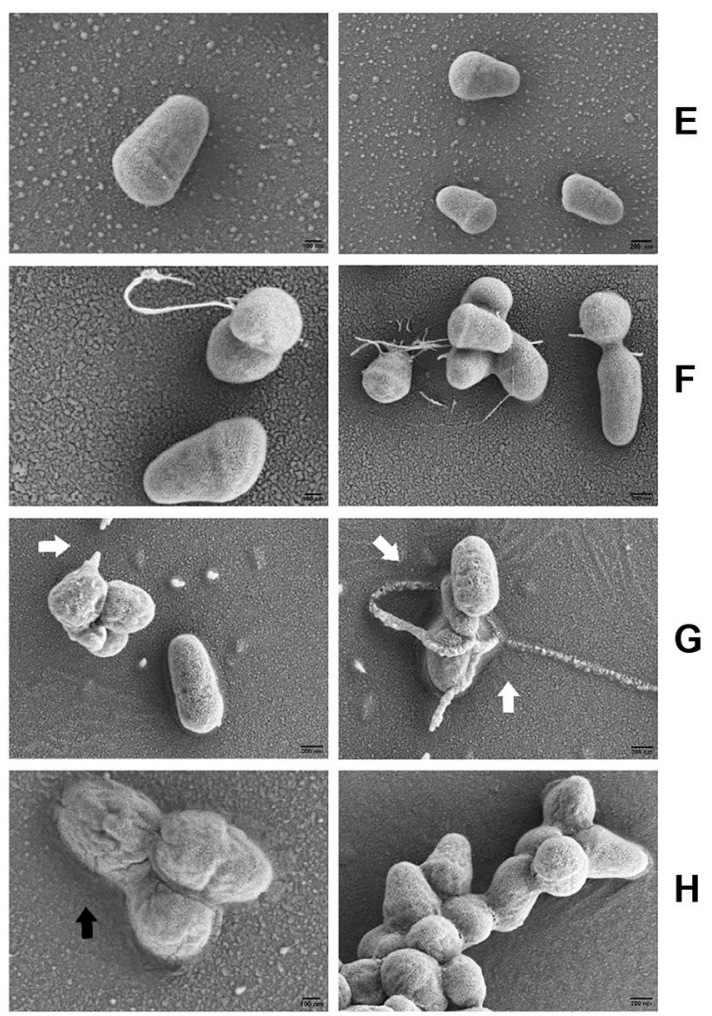

$\mathrm{Jls} \mathrm{cm} \mathrm{c}^{-2}$ of UV-B (15 min), D, H $1.04 \mathrm{Jls.cm}{ }^{-2}$ of UV-B (30 min). The black arrows indicate morphologic changes $(\mathbf{C})$, the white arrows cell damage (C) and pili deterioration $(\mathbf{G})$. Scale bar $200 \mathrm{~nm}(\mathbf{E}-\mathbf{H})$, $100 \mathrm{~nm}(\mathbf{A}-\mathbf{F}, \mathbf{H})$

\section{Genomic insights into the Act20 biotechnologic potential}

Act20 is a halophile with enormous biotechnologic potential, as the bacterium encodes haloenzymes and proteins with applications in the current food, paper, fuel, and chemical industries and in waste treatment; medicine; cosmetics; biocontrol; pharmacology; and bioremediation (Table S8).

Act 20 could degrade wasted vegetal biomass, especially lignocellulose derivatives, as the bacterium encodes $\alpha$-xylosidase, xylanases, xylose isomerases, and an $\alpha$-arabinofuranosidase. A chitinase is also present, which enzyne confers the potential to degrade wasted animal biomass. The genome of Act 20 furthermore possesses the possibility of producing some exciting compounds of interest-including bacterial cellulose, a compound with an emerging number of applications such as nanoparticle science and regenerative medicine (Gullo et al. 2018); bacterial hemoglobin, which protein has been found to enhance 
Fig. 4 TEM micrographs of actinobacteria cells after exposure to UV-B radiation. A-D $N$. sp. Act20. E-H $N$. halotolerans DSM 15,474. A, E Nonexposed growing bacterial cells (control). Growing bacterial cells exposed to $(\mathbf{B}, \mathbf{F}) 0.17 \mathrm{Jls} \mathrm{cm}^{-2}$ of UV-B ( $5 \mathrm{~min}), \mathbf{C}, \mathbf{G} 0.51$

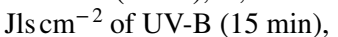
D, H $1.04 \mathrm{Jls} \mathrm{cm}^{-2}$ of UV-B (30 min). Scale bars, $200 \mathrm{~nm}$ in the main panels and $50 \mathrm{~nm}$ in the insets
A
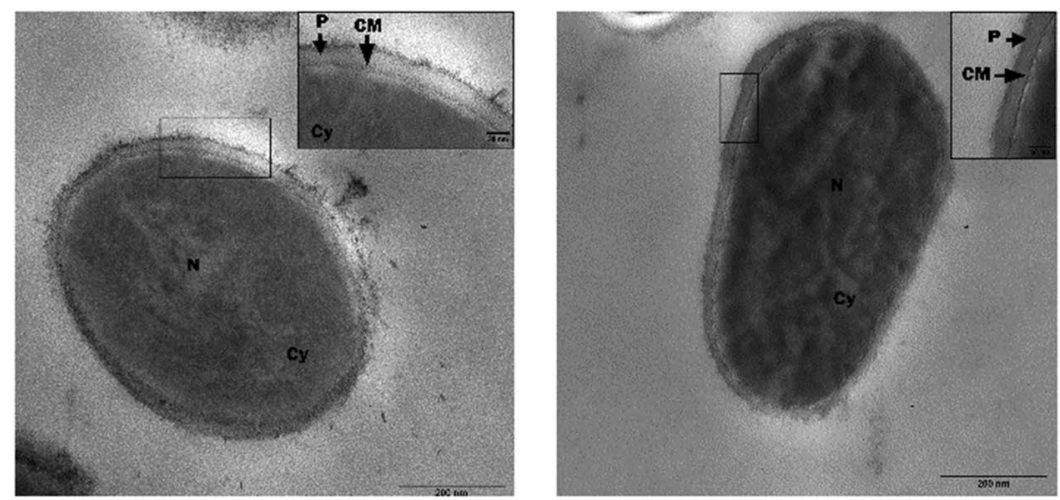

E
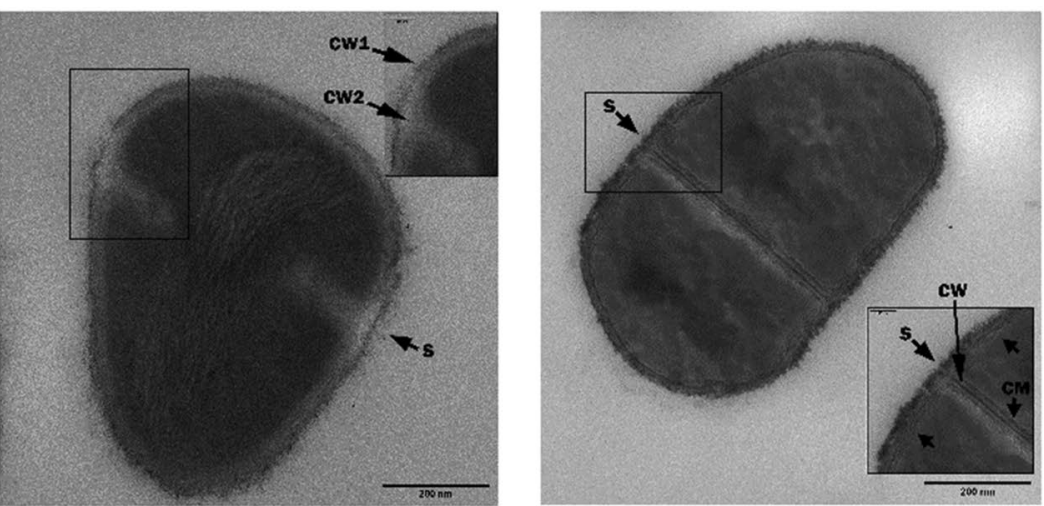

$\boldsymbol{F}$

\section{B}
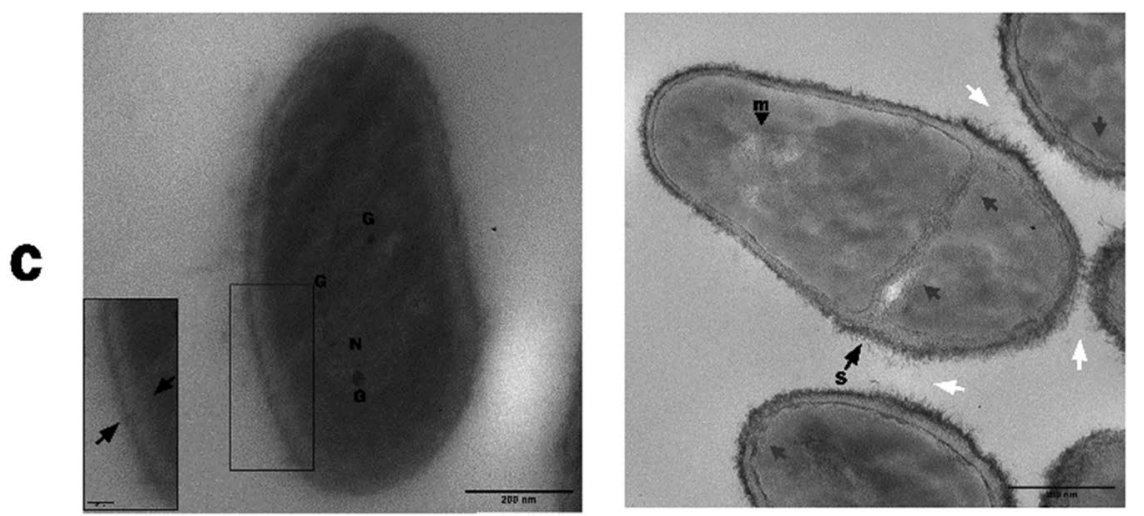

G
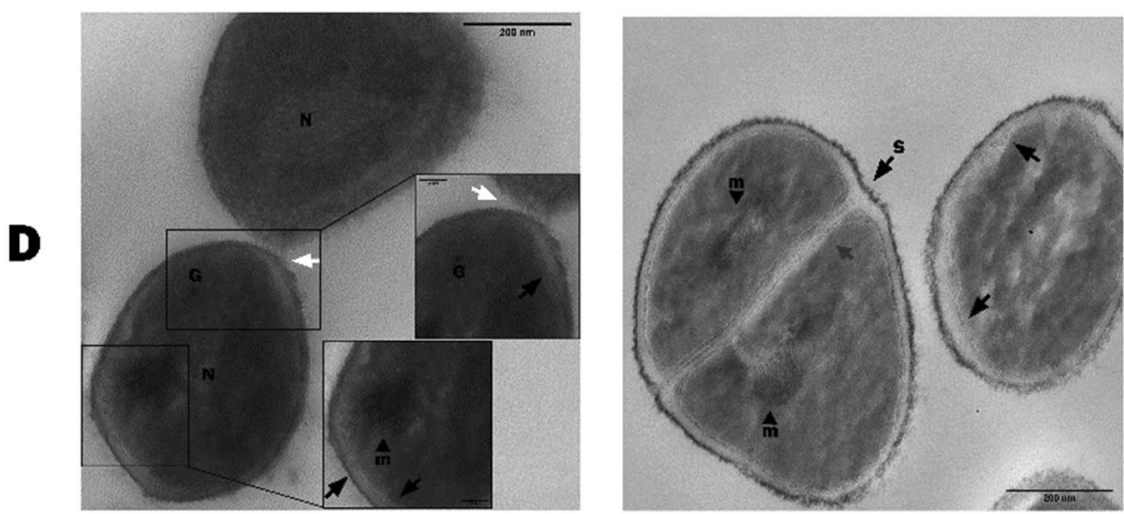
bioproduction under low-oxygen conditions (Frey and Kallio 2003); promising antibiotics like colicin and aurachin (Gerhard Hofle et al. 1987; Oettmeier et al. 1994; Gérard et al. 2005; Mousa et al. 2016); and the protein Cry26Aa with high insecticide properties (Wojciechowska et al. 1999). Another relevant enzyme provided by the Act 20 genome is the $\alpha$-sialidase, whose catalytic activity has been proven to be useful in synthesizing sialylated glycoproteins (Kim et al. 2011) that are highly suitable for pharmacology (Varki 2008).

\section{Discussion}

Nesterenkonia strains have been frequently isolated from environmental niches, including saline locations other than the Andes (Yoon et al. 2006; Amiri et al. 2016). That the ecology of these diverse habitats defines the genetic differentiation of Nesterenkonia has been demonstrated. Such genetic differentiation is a key feature of Act20's the genome, as it shares a low sequence similarity to those of other strains within the set of genomes analyzed by ANI. The genomic and physiologic particularities suggest that Act20 may be a new species adapted to the high-altitudeAndean-Lake (HAAL) environment and one inspiring new areas of investigation (Fig. 1).

Act20's copper and desiccation resistance described in the Results section is coincident with several genetic sequences found in the genome, potentially involved in such resistance. The abundance of direct and indirect mechanisms implicated in the copper resistance is indeed noteworthy: some of these forms of resistance were well studied in Gram-negative bacteria and are performed by periplasmic proteins; which gene products, though, are not likely to exist the Gram-positive Act20 lacking an outer membrane and periplasm (Giachino and Waldron 2020). Likewise, the desiccation resistance relies on the production of a wide diversity of osmoprotectants that creates a hydrostatic force in the cytoplasm. The puzzling characteristic is that the MdoB protein would produce such a hydrostatic pressure only in the periplasm. In both instances, the assessment of whether or not the Act 20 cell-wall structure can accommodate a periplasmic-like space where the described gene products can function as proposed for Gram-negative bacteria will be interesting. A periplasmic space has been reported for other Gram-positive bacteria (Matias and Beveridge 2005; Zuber et al. 2006).

A particular cytosolic copper-storage protein in the annotation analysis drew our attention. The function and existence of that protein are controversial since a widely accepted view is that bacteria have not evolved to use intracelullar copper accumulation because of potential toxicity associated with such a metalation (Dennison et al.
2018). Note that this protein was initially discovered in the Gram-negative methane-oxidizing bacterium (methanotroph) Methylosinus trichosporium OB3b, which species uses large amounts of copper to metabolize methane via the membrane-bound (particulate) methane monooxygenase (Vita et al. 2015). Nevertheless, the role of this form of copper storage in Act20, which property can otherwise work as an additional osmoprotectant, is not clear. More research will be needed to confirm the copper-bioaccumation ability of Act20, a mechanism useful for the design of bioremediation processes and applicable to the cleanup of several pollutant activities such as industry and mining.

The complete set of genes for the ectoine synthetic cluster is present in the Act 20 genome (Fig. S3), conferring on the strain an excellent potential for future biotechnological applications. Ectoine is a water-binding zwitterionic amino-acid derivative with numerous biotechnological applications and is a common component of cosmetic antiaging and moisturizing creams to improve skin resistance to surfactants in skin-cleansing solutions. Ectoine also alleviates skin inflammation and is currently recommended to treat moderate atopic dermatitis (Bownik and Stẹpniewska 2016). Furthermore, the compound is useful in sunscreens as it strongly absorbs UV radiation and in diverse cell types protects DNA from breaking down. Ectoine also has other notable applications in medicine (Bownik and Stępniewska 2016).

The genome of Act20 joins others already sequenced from HAAL extremophilic prokaryotes (Farias et al. 2011; Ordoñez et al. 2013, 2015; Burguener et al. 2014) that have genes for arsenic metabolism, as the first of the Nesterenkonia genus having been reported for an environment with a high concentration of arsenic. We propose that, in Act20, this resistance occurs by reducing As [V] to As [III] with a mycothiol-dependent arsenate reductase and the subsequent efflux of As [III] from the cell through specific transporters (Ordóñez et al. 2009), thus making this bacterium the first HAAL genome effecting the reduction of As [V] to As [III] through the mycothiol-thioredoxinredox pathway.

The selection of UV-resistome-gene abundance and diversity in aquatic microbiomes by solar-irradiation intensity was previously evidenced by our group using a worldwide metagenomic analysis (Alonso-Reyes et al. 2020). In the same way as the those in the metagenomics study, the Act 20 genome has a more sophisticated UV-resistome with respect to a higher quantity and diversity of genes devoted to UV resistance than other less-irradiated strains. We also observed a similar pattern for other Nesterenkonia from high altitudes or expected highly irradiated environments (Fig. 2, Table S7). Thus, our present findings at the genomic level added support for the relationship between solar radiation and the complexity of the UV-resistome. 
Notable within the subsystem of UV evasion and/or shielding are the genes involved in the production of gas vesicles (the gvpA, K, O, and $\mathrm{F}$ ). The expression of gas vesicles (Damerval et al. 1991; Englert et al. 1992; Pfeifer 2012) along with flagella, enable microbes to move up in the water column toward sunlight. In many instances, however, these vesicles are also present in soil prokaryotes, even from high-UV-radiation environments, thus suggesting new roles in radiation protection (Oren 2012). That these vesicles could change the cell's positioning with respect to the angle of the incident light, thus increasing the impact of the radiation on the cell has been speculated (Bolhuis et al. 2006; Oren 2012). In addition, our current studies on comparative proteomics have revealed an increase in vesicle-protein expression in response to increases in UV (Zannier et al. 2021). We also included flagella, swarming-motility proteins and the pili, whose ability to promote bacterial aggregation or biofilm adhesion may protect the cells from UV exposure (OjanenReuhs et al. 1997; Burdman et al. 2011). All these genes were well represented in the Act20 genome.
The Act20 genome encodes resistance genes to other extreme conditions: low temperatures, low atmospheric$\mathrm{O}_{2}$ pressure, and stress from heavy metals and other toxic compounds. Many of these hard environmental conditions added to the aforementioned along with the geophysical characteristics of the sampling site in combination (Fig. 5) resemble those present in the early Earth's atmosphere that gave rise to the evolution of the ancient microorganisms (Cabrol et al. 2007; Albarracín et al. 2015; Cockell et al. 2000; Yen et al. 2006; Karunatillake et al. 2007; Hecht et al. 2009; Sforna et al. 2014; Forni et al. 2015; Wadsworth and Cockell 2017). Thus, Act20 is an exciting model organism to study the mechanisms by which the extremophiles could have successfully faced the adverse conditions of the Earth's primordial history, with also clear implications in astrobiological projects (Hiscox and Thomas 1995; Slotnick 2000; Merino et al. 2019).

Act 20 could also have a great biotechnological potential for producing enzymes and metabolizing compounds of interest (Table S8). Bacterial cellulose, hemoglobin, antibiotics, and a potential insecticide are among the Act20

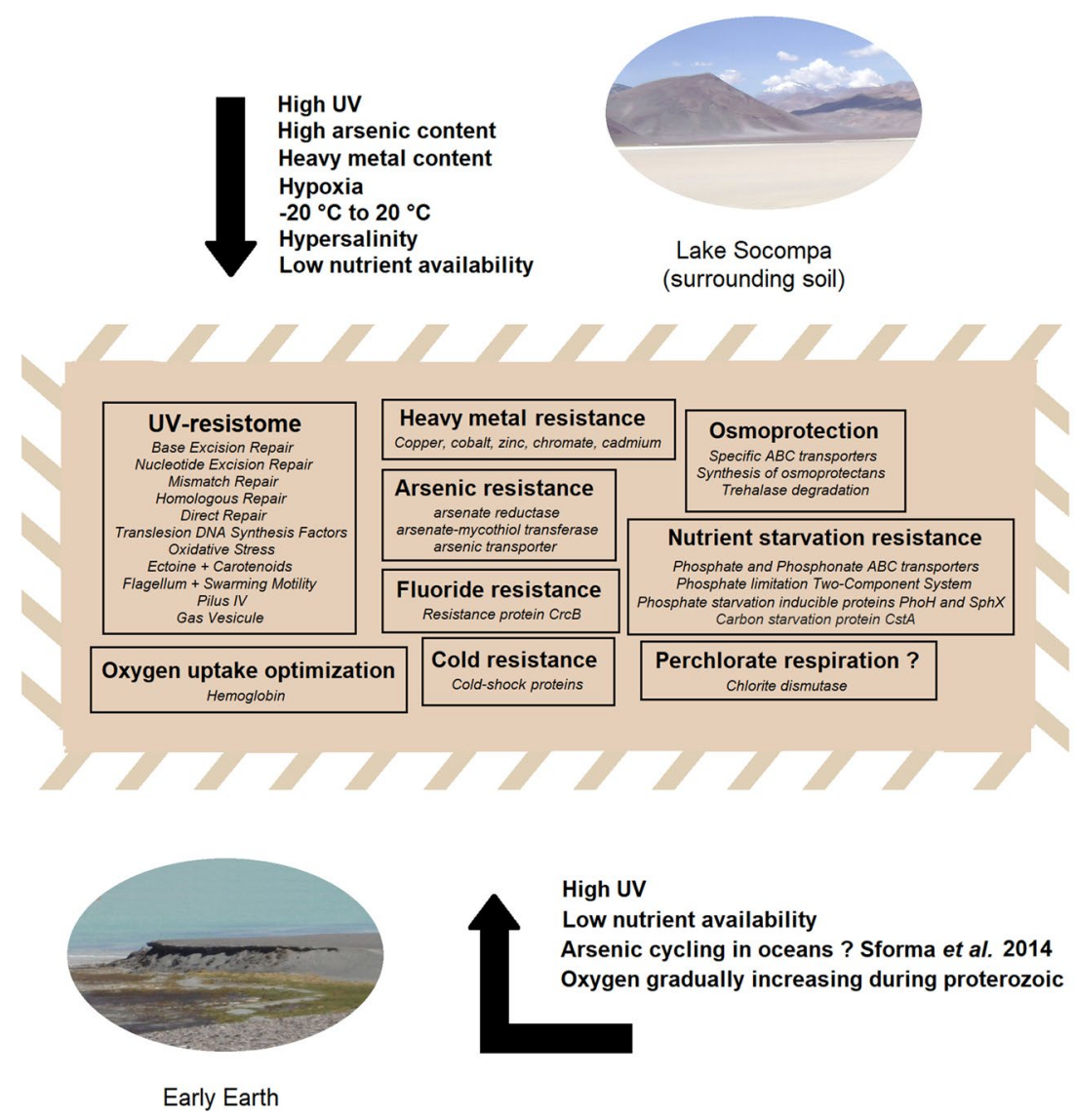

Lake Socompa

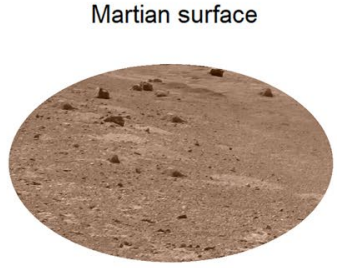

High UV

High heavy metal content Perchlorates

Fluorine containing minerals Hypersalinity $-140^{\circ} \mathrm{C}$ to $30^{\circ} \mathrm{C}$
Fig. 5 Comparison between the extreme conditions (relevant to Act20) of the Lake Socompa, the Mars surface, and the early-Earth environments. The light-brown box summarizes the plethora of genetic activities and properties of the Act20 genome and its potential for the different resistances as described inside. The photos depicting the terrain of Lake Socompa, the surface of Mars, and a simulation of the early-Earth environment are illustrative 
biosynthetic products. In addition, several genes for enzymes capable of degrading vegetal biomass were also detected. This feature is of practical relevance to the biodegradation of lignocellulosic biomass of the agro-industrial wastes that are produced in large amounts through agricultural and forestry practices, including the paper-and-pulp and timber industries. Likewise, animal biomass that contains high proportions of shellfish — such as shrimp, crab, and krill-is suitable to be processed through chitinases, an enzyme that is also present in Act20. The seafood-processing industry has raised serious concerns regarding disposal issues because of the resulting waste's low biodegradation rate, which impasse could be solved through an enzymatic approach.

The enzymes mentioned above could be used in industrial processes that reproduce the microbe's original natural habitat's extreme conditions. Biocatalysts isolated from these extremophiles are termed extremozymes and possess special salt toleration, thermostability, and cold adaptivity. Extremozymes are highly resistant to severe conditions owing to their great versatility. As such, they represent novel prospects for biocatalysis and biotransformations and the development of the economy along with unique lines of research through their application (Dumorné et al. 2017). Accordingly, we also report here the genetic potential of Act20 to provide poly-extremozymes, which could combine resistance to cold temperatures $\left(-2{ }^{\circ} \mathrm{C}-20^{\circ} \mathrm{C}\right)$, high solar radiation, salinity (at least $1 \mathrm{M}$ salt), and high $\mathrm{pH}(>8)$. Enzymes of this halophilic microbe could provide great opportunities, particularly for the food, bioremediation, and pharmaceutical industries.

In summary, in this report, we described the genomic basis of the multiresistance phenotype of strain Act20, especially towards UV radiation, copper, and desiccation. The potential of this bacterium with respect to the production of enzymes and compounds useful for biotechnology was likewise explored. Act20 becomes an exciting candidate for additional studies of transcriptomics, proteomics (currently in progress), metabolomics, as well as the expression and testing of biotech-competent enzymes. This work has thus shed light on the mechanisms of microbial adaptation to highaltitude environments, with a possible extrapolation to the study of other extreme environments of relevance along with an application to industrial and biotechnological processes.

Supplementary Information The online version contains supplementary material available at https://doi.org/10.1007/s11274-021-03129-9

Acknowledgements The authors acknowledge the generous financial support by PIUNT G603, PIP CONICET 0519 and PICT 2019-3216 projects. VHA, MPV, and MEF are staff researchers from the National Research Council (CONICET) in Argentina. DA, MSG, NNA are the recipients of doctoral fellowships from CONICET. The Act20 genome-sequencing project was performed in INDEAR-CONICET, Argentina. The electron micrographs used in this study were taken at the Center for Electron Microscopy (CIME) belonging to UNT and
CCT, CONICET, Tucumán. This manuscript has been released as a Pre-Print at bioRxiv. We thank Dr. Donald F. Haggerty for his help in the final revision of the manuscript.

Author contributions DGAR and VA designed and performed the research, and wrote the paper. DGAR carried out phylogenetic and genomic analysis. FSG, LRP and NNA performed physiological experiments and subsequent analyses. MEF and VA obtained funding for the original project idea. MEF performed sampling expeditions and provided strains for the present project. MPV provided the sequencing platform and tools, and conducted quality control and genome assembling.

Funding This study was funded by PIUNT G603, PIP CONICET 0519 and PICT 2019-3216 projects.

Data availability The datasets generated and/or analyzed during the current study are available from the corresponding author on reasonable request.

\section{Declarations}

Conflict of interest The authors declare no competing interests exist.

Consent to participate Informed consent was obtained from all individual participants included in the study.

Consent for publication All authors read and approved this manuscript.

\section{References}

Albarracín VH, Winik B, Kothe E et al (2008) Copper bioaccumulation by the actinobacterium Amycolatopsis sp. AB0. J Basic Microbiol 48:323-330. https://doi.org/10.1002/jobm.200700360

Albarracín VH, Simon J, Pathak GP et al (2014) First characterisation of a CPD-class i photolyase from a UV-resistant extremophile isolated from high-altitude Andean Lakes. Photochem Photobiol Sci 13:739-750. https://doi.org/10.1039/c3pp50399b

Albarracín VH, Kurth D, Ordoñez OF et al (2015) High-up: a remote reservoir of microbial extremophiles in Central Andean wetlands. Front Microbiol 6:1404. https://doi.org/10.3389/fmicb.2015. 01404

Albarracín VH, Gärtner W, Farias ME (2016) Forged under the sun: life and art of extremophiles from Andean Lakes. Photochem Photobiol 92:14-28. https://doi.org/10.1111/php.12555

Albarracı VH, Farías ME (2012) Biotecnología turquesa. Rev Hipótesis 13:32-39

Alonso-Reyes DG, Farias ME, Albarracín VH (2020) Uncovering cryptochrome/photolyase gene diversity in aquatic microbiomes exposed to diverse UV-B regimes. Aquat Microb Ecol 85:141154. https://doi.org/10.3354/AME01947

Amiri H, Azarbaijani R, Parsa Yeganeh L et al (2016) Nesterenkonia sp. strain F, a halophilic bacterium producing acetone, butanol and ethanol under aerobic conditions. Sci Rep 6:18408. https:// doi.org/10.1038/srep18408

Atichartpongkul S, Loprasert S, Vattanaviboon P et al (2001) Bacterial $\mathrm{Ohr}$ and OsmC paralogues define two protein families with distinct functions and patterns of expression. Microbiology 147:1775-1782. https://doi.org/10.1099/00221287-147-7-1775

Arnesano F, Banci L, Bertini I et al (2003) A redox switch in CopC: an intriguing copper trafficking protein that binds copper(I) and 
copper(II) at different sites. Proc Natl Acad Sci U S A 100:38143819. https://doi.org/10.1073/pnas.0636904100

Bequer Urbano S, Albarracín VH, Ordoñez OF et al (2013) Lipid storage in high-altitude Andean Lakes extremophiles and its mobilization under stress conditions in Rhodococcus sp. A5, a UV-resistant actinobacterium. Extremophiles 17:217-227. https://doi.org/10. 1007/s00792-012-0508-2

Boch J, Kempf B, Schmid R, Bremer E (1996) Synthesis of the osmoprotectant glycine betaine in Bacillus subtilis: characterization of the gbsAB genes. J Bacteriol 178:5121-5129. https://doi.org/10. 1128/jb.178.17.5121-5129.1996

Boch J, Nau-Wagner G, Kneip S, Bremer E (1997) Glycine betaine aldehyde dehydrogenase from Bacillus subtilis: characterization of an enzyme required for the synthesis of the osmoprotectant glycine betaine. Arch Microbiol 168:282-289. https://doi.org/10. 1007/s002030050500

Bolhuis H, Palm P, Wende A et al (2006) The genome of the square archaeon Haloquadratum walsbyi: life at the limits of water activity. BMC Genom 7:169. https://doi.org/10.1186/1471-2164-7-169

Bownik A, Stępniewska Z (2016) Ectoine as a promising protective agent in humans and animals. Arh Hig Rada Toksikol 67:260 265. https://doi.org/10.1515/aiht-2016-67-2837

Bozzola JJ (2007) Conventional specimen preparation techniques for scanning electron microscopy of biological specimens. Methods Mol Biol 369:449-466. https://doi.org/10.1007/978-1-59745-294$6 \_22$

Brinster S, Furlan S, Serror P (2007) C-terminal WxL domain mediates cell wall binding in Enterococcus faecalis and other gram-positive bacteria. J Bacteriol 189:1244-1253. https://doi.org/10.1128/JB. 00773-06

Burdman S, Bahar O, Parker JK, de la Fuente L (2011) Involvement of type IV pili in pathogenicity of plant pathogenic bacteria. Genes (Basel) 2:706-735. https://doi.org/10.3390/genes2040706

Burguener GF, Maldonado MJ, Revale S et al (2014) Draft genome sequence of the polyextremophilic Halorubrum sp. strain AJ67, isolated from Hyperarsenic Lakes in the Argentinian Puna. Genome Announc 2:e01096-e01013. https://doi.org/10.1128/ genomeA.01096-13

Burroughs AM, Zhang D, Schäffer DE et al (2015) Comparative genomic analyses reveal a vast, novel network of nucleotidecentric systems in biological conflicts, immunity and signaling. Nucleic Acids Res 43:10633-10654. https://doi.org/10.1093/nar/ gkv1267

Cabrol NA, McKay CP, Grin EA et al (2007) Signatures of habitats and life in Earth's high-altitude lakes clues to noachian aqueous environments on Mars. In: Chapman M (ed) The geology of Mars evidence from Earth-based analogs. Cambridge University Press, Cambridge, pp 349-370

Carroll JD, Pastuszak I, Edavana VK et al (2007) A novel trehalase from Mycobacterium smegmatis - Purification, properties, requirements. FEBS J 274:1701-1714. https://doi.org/10.1111/j. 1742-4658.2007.05715.x

Cockell CS, Catling DC, Davis WL et al (2000) The ultraviolet environment of Mars: biological implications past, present, and future. Icarus 146:343-359. https://doi.org/10.1006/icar.2000.6393

Chauvaux S, Chevalier F, Le Dantec C et al (2001) Cloning of a genetically unstable cytochrome P-450 gene cluster involved in degradation of the pollutant ethyl tert-butyl ether by Rhodococcus ruber. J Bacteriol 183:6551-6557. https://doi.org/10.1128/JB.183.22. 6551-6557.2001

Damerval T, Castets A-M, Houmard J, de Marsac NT (1991) Gas vesicle synthesis in the cyanobacterium Pseudanabaena sp.: occurrence of a single photoregulated gene. Mol Microbiol 5:657-664. https://doi.org/10.1111/j.1365-2958.1991.tb00737.x
Dennison C, David S, Lee J (2018) Bacterial copper storage proteins. J Biol Chem 293:4616-4627. https://doi.org/10.1074/jbc.TM117. 000180

Dumorné K, Córdova DC, Astorga-Eló M, Renganathan P (2017) Extremozymes: a potential source for industrial applications. J Microbiol Biotechnol 27:649-659. https://doi.org/10.4014/jmb. 1611.11006

Englert C, Krüger K, Offner S, Pfeifer F (1992) Three different but related gene clusters encoding gas vesicles in halophilic archaea. J Mol Biol 227:586-592. https://doi.org/10.1016/0022-2836(92) 90914-6

Farias ME, Revale S, Mancini E et al (2011) Genome sequence of Sphingomonas sp. S17 isolated from an alkaline, hyperarsenic and hypersaline volcanic associated lake near 4000 meters above sea level in the Argentinean Puna. J Bacteriol. https://doi.org/10. 1128/JB.05225-11

Felux AK, Spiteller D, Klebensberger J, Schleheck D (2015) EntnerDoudoroff pathway for sulfoquinovose degradation in Pseudomonas putida SQ1. Proc Natl Acad Sci U S A 112:E4298E4305. https://doi.org/10.1073/pnas.1507049112

Forni O, Gaft M, Toplis MJ et al (2015) First detection of fluorine on Mars: implications for Gale Crater's geochemistry. Geophys Res Lett 42:1020-1028. https://doi.org/10.1002/2014GL062742

Frey AD, Kallio PT (2003) Bacterial hemoglobins and flavohemoglobins: versatile proteins and their impact on microbiology and biotechnology. FEMS Microbiol Rev 27:525-545. https://doi.org/ 10.1016/S0168-6445(03)00056-1

Gérard F, Pradel N, Wu L-F (2005) Bactericidal activity of colicin V is mediated by an inner membrane protein $\mathrm{SdaC}$ of Escherichia coli. J Bacteriol 187:1945-1950. https://doi.org/10.1128/JB.187.6. 1945-1950.2005

Gerhard Hofle BK, Reichenbach H, Hofle G (1987) The aurachins, new quinoline antibiotics from myxobacteria: production, physicochemical and biological properties. J Antibiot (Tokyo) 40:258265. https://doi.org/10.7164/antibiotics.40.258

Giachino A, Waldron KJ (2020) Copper tolerance in bacteria requires the activation of multiple accessory pathways. Mol Microbiol 114:377-390. https://doi.org/10.1111/mmi.14522

Gul N, Poolman B (2013) Functional reconstitution and osmoregulatory properties of the ProU ABC transporter from Escherichia coli. Mol Membr Biol 30:138-148. https://doi.org/10.3109/09687 688.2012.754060

Gullo M, La China S, Falcone PM, Giudici P (2018) Biotechnological production of cellulose by acetic acid bacteria: current state and perspectives. Appl Microbiol Biotechnol 102:6885-6898. https://doi.org/10.1007/s00253-018-9164-5

Harke MJ, Gobler CJ (2013) Global transcriptional responses of the toxic cyanobacterium, microcystis aeruginosa, to nitrogen stress, phosphorus stress, and growth on organic matter. PLoS One 8. https://doi.org/10.1371/journal.pone.0069834

Hecht MH, Kounaves SP, Quinn RC et al (2009) Detection of perchlorate and the soluble chemistry of Martian soil at the phoenix lander site. Science 325:64-67. https://doi.org/10.1126/science. 1172466

Hénin J, Tajkhorshid E, Schulten K, Chipot C (2008) Diffusion of glycerol through Escherichia coli aquaglyceroporin GlpF. Biophys J 94:832-839. https://doi.org/10.1529/biophysj.107.115105

Hiscox J, Thomas D (1995) Genetic modification and selection of microorganisms for growth on Mars. J Br Interplanet Soc 48:419-426

Kalscheuer R, Weinrick B, Veeraraghavan U et al (2010) Trehaloserecycling $\mathrm{ABC}$ transporter LpqY-SugA-SugBSugC is essential for virulence of Mycobacterium tuberculosis. Proc Natl Acad Sci 107:21761-21766. https://doi.org/10.1073/pnas.1014642108

Kappes RM, Kempf B, Kneip S et al (1999) Two evolutionarily closely related $\mathrm{ABC}$ transporters mediate the uptake of choline 
for synthesis of the osmoprotectant glycine betaine in Bacillus subtilis. Mol Microbiol 32:203-216. https://doi.org/10.1046/j. 1365-2958.1999.01354.x

Kaspy I, Rotem E, Weiss N et al (2013) HipA-mediated antibiotic persistence via phosphorylation of the glutamyltRNA- synthetase. Nat Commun 4:3001. https://doi.org/10.1038/ncomms4001

Karunatillake S, Keller JM, Squyres SW et al (2007) Chemical compositions at Mars landing sites subject to Mars odyssey gamma ray spectrometer constraints. J Geophys Res Planets. https://doi. org/10.1029/2006JE002859

Kim S, Oh DB, Kang HA, Kwon O (2011) Features and applications of bacterial sialidases. Appl Microbiol Biotechnol 91:1-15. https://doi.org/10.1007/s00253-011-3307-2

Kiran GS, Priyadharsini S, Sajayan A et al (2017) Production of lipopeptide biosurfactant by a Marine Nesterenkonia sp. and its application in food industry. Front Microbiol 8:1138

Kurth D, Belfiore C, Gorriti MF et al (2015) Genomic and proteomic evidences unravel the UV-resistome of the poly-extremophile Acinetobacter sp. Ver3. Front Microbiol 6:1-18. https://doi.org/ 10.3389/fmicb.2015.00328

Kurtz S, Phillippy A, Delcher AL et al (2004) Versatile and open software for comparing large genomes. Genome Biol 5:R12. https://doi.org/10.1186/gb-2004-5-2-r12

Lamark T, Røkenes TP, McDougall J, Strøm AR (1996) The complex bet promoters of Escherichia coli: regulation by oxygen (ArcA), choline (BetI), and osmotic stress. J Bacteriol 178:1655-1662. https://doi.org/10.1128/jb.178.6.1655-1662.1996

Lechner M, Findeiß S, Steiner L et al (2011) Proteinortho: detection of (Co-)orthologs in large-scale analysis. BMC Bioinform 12:124. https://doi.org/10.1186/1471-2105-12-124

Letunic I, Bork P (2016) Interactive tree of life (iTOL) v3: an online tool for the display and annotation of phylogenetic and other trees. Nucleic Acids Res 44:W242-W245. https://doi.org/10. 1093/nar/gkw290

Lucht JM, Bremer E (1994) Adaptation of Escherichia coli to high osmolarity environments: osmoregulation of the high-affinity glycine betaine transport system ProU. FEMS Microbiol Rev 14:3-20. https://doi.org/10.1111/j.1574-6976.1994.tb00067.x

Matias VRF, Beveridge TJ (2005) Cryo-electron microscopy reveals native polymeric cell wall structure in Bacillus subtilis 168 and the existence of a periplasmic space. Mol Microbiol 56:240251. https://doi.org/10.1111/j.1365-2958.2005.04535.x

Matsuzawa T, Kimura N, Suenaga H, Yaoi K (2016) Screening, identification, and characterization of $\alpha$-xylosidase from a soil metagenome. J Biosci Bioeng 122:393-399. https://doi.org/10.1016/j. jbiosc.2016.03.012

Merino N, Aronson HS, Bojanova DP et al (2019) Living at the extremes: extremophiles and the limits of life in a planetary context. Front Microbiol 10:780. https://doi.org/10.3389/fmicb. 2019.00780

Mousa WK, Shearer C, Limay-Rios V et al (2016) Root-hair endophyte stacking in finger millet creates a physicochemical barrier to trap the fungal pathogen Fusarium graminearum. Nat Microbiol 1:16167. https://doi.org/10.1038/nmicrobiol.2016.167

Nagata S, Wang YB (2001) Accumulation of ectoine in the halotolerant Brevibacterium sp. JCM 6894. J Biosci Bioeng 91:288-293. https://doi.org/10.1016/S1389-1723(01)80136-5

Oettmeier W, Masson K, Soll M, Reil E (1994) Acridones and quinolones as inhibitors of ubiquinone functions in the mitochondrial respiratory chain. Biochem Soc Trans 22:213-216. https:// doi.org/10.1042/bst0220213

Ojanen-Reuhs T, Kalkkinen N, Westerlund-Wikström B et al (1997) Characterization of the fimA gene encoding bundle-forming fimbriae of the plant pathogen Xanthomonas campestris pv. vesicatoria. J Bacteriol 179:1280-1290. https://doi.org/10.1128/ jb.179.4.1280-1290.1997
Ordoñez OF, Lanzarotti E, Kurth D et al (2013) Draft genome sequence of the polyextremophilic Exiguobacterium sp. strain S17, isolated from Hyperarsenic Lakes in the Argentinian Puna. Genome Announc 1:e00480-e00413. https://doi.org/10.1128/genomeA. 00480-13

Ordoñez O, Lanzarotti E, Kurth D et al (2015) Genome comparison of two Exiguobacterium strains from high altitude Andean lakes with different arsenic resistance: identification and 3D modeling of the Acr3 efflux pump. Front Environ Sci 3:50

Ordóñez E, Van Belle K, Roos G et al (2009) Arsenate reductase, mycothiol, and mycoredoxin concert thiol/disulfide exchange. J Biol Chem 284:15107-15116. https://doi.org/10.1074/jbc.M9008 77200

Oren A (2012) The function of gas vesicles in halophilic archaea and bacteria: theories and experimental evidence. Life 3:1-20. https:// doi.org/10.3390/life3010001

Pfeifer F (2012) Distribution, formation and regulation of gas vesicles. Nat Rev Microbiol 10:705-715. https://doi.org/10.1038/ nrmicro2834

Portero LR, Alonso-Reyes DG, Zannier F et al (2019) Photolyases and cryptochromes in UV-resistant bacteria from high-altitude Andean lakes. Photochem Photobiol 95:315-330. https://doi.org/ 10.1111/php.13061

Prabhakar Y, Gupta A, Kaushik A (2019) Enhanced decolorization of reactive violet dye 1 by halo-alkaliphilic nesterenkonia strain: process optimization, short acclimatization and reusability analysis in batch cycles. Process Saf Environ Prot 131:116-126. https:// doi.org/10.1016/j.psep.2019.09.004

Price MN, Dehal PS, Arkin AP (2010) FastTree 2 - approximately maximum-likelihood trees for large alignments. PLoS ONE 5:e9490

Pruesse E, Peplies J, Glöckner FO (2012) SINA: accurate highthroughput multiple sequence alignment of ribosomal RNA genes. Bioinformatics 28:1823-1829. https://doi.org/10.1093/bioinforma tics/bts252

Rasuk MC, Ferrer GM, Kurth D et al (2017) UV-resistant actinobacteria from high-altitude Andean lakes: isolation, characterization and antagonistic activities. Photochem Photobiol 93:865-880. https://doi.org/10.1111/php.12759

Reshetnikov AS, Khmelenina VN, Trotsenko YA (2006) Characterization of the ectoine biosynthesis genes of haloalkalotolerant obligate methanotroph "Methylomicrobium alcaliphilum 20Z". Arch Microbiol 184:286-297. https://doi.org/10.1007/ s00203-005-0042-Z

Richter M, Rosselló-Móra R (2009) Shifting the genomic gold standard for the prokaryotic species definition. Proc Natl Acad Sci USA 106:19126-19131. https://doi.org/10.1073/pnas.0906412106

Rothe M, Alpert C, Loh G, Blaut M (2013) Novel Insights into E. coli's hexuronate metabolism: KduI facilitates theconversion of galacturonate and glucuronate under osmotic stress conditions. PLoS One 8:e56906

Seemann T (2014) Prokka: rapid prokaryotic genome annotation. Bioinformatics 30:2068-2069. https://doi.org/10.1093/bioinforma tics/btu153

Sforna MC, Philippot P, Somogyi A et al (2014) Evidence for arsenic metabolism and cycling by microorganisms 2.7 billion years ago. Nat Geosci 7:811-815. https://doi.org/10.1038/ngeo2276

Sleator RD, Hill C (2002) Bacterial osmoadaptation: the role of osmolytes in bacterial stress and virulence. FEMS Microbiol Rev 26:49-71. https://doi.org/10.1111/j.1574-6976.2002.tb00598.x

Slotnick RS (2000) Extremophilic terraforming. Am Sci 88:124

Solon AJ, Vimercati L, Darcy JL et al (2018) Microbial communities of high-elevation fumaroles, penitentes, and dry tephra "soils" of the Puna de Atacama volcanic zone. Microb Ecol 76:340-351. https://doi.org/10.1007/s00248-017-1129-1 
Stackebrandt E, Koch C, Gvozdiak O, Schumann P (1995) Taxonomic dissection of the genus Micrococcus: Kocuria gen. nov., Nesterenkonia gen. nov., Kytococcus gen. nov., Dermacoccus gen. nov., and Micrococcus cohn 1872 gen. emend. Int J Syst Bacteriol 45:682-692. https://doi.org/10.1099/00207713-45-4-682

Styrvold OB, Strom AR (1991) Synthesis, accumulation, and excretion of trehalose in osmotically stressed Escherichia coli K-12 strains: influence of amber suppressors and function of the periplasmic trehalase. J Bacteriol 173:1187-1192. https://doi.org/10.1128/jb. 173.3.1187-1192.1991

Varki A (2008) Sialic acids in human health and disease. Trends Mol Med 14:351-360. https://doi.org/10.1016/j.molmed.2008.06.002

Vita N, Platsaki S, Baslé A et al (2015) A four-helix bundle stores copper for methane oxidation. Nature 525:140-143. https://doi. org/10.1038/nature14854

Wadsworth J, Cockell CS (2017) Perchlorates on Mars enhance the bacteriocidal effects of UV light. Sci Rep 7:4662. https://doi.org/ 10.1038/s41598-017-04910-3

Wojciechowska JA, Lewitin E, Revina LP et al (1999) Two novel deltaendotoxin gene families cry 26 and cry 28 from Bacillus thuringiensis ssp. finitimus. FEBS Lett 453:46-48. https://doi.org/10. 1016/S0014-5793(99)00650-X

Wood JM (1988) Proline porters effect the utilization of proline as nutrient or osmoprotectant for bacteria. J Membr Biol 106:183202. https://doi.org/10.1007/BF01872157

Xu Q, Bateman A, Finn RD et al (2010) Bacterial pleckstrin homology domains: a prokaryotic origin for the PH domain. J Mol Biol 396:31-46. https://doi.org/10.1016/j.jmb.2009.11.006

Yen A, Mittlefehldt D, McLennan S et al (2006) Nickel on Mars: constraints on meteoritic material at the surface. J Geophys Res. https://doi.org/10.1029/2006JE002797
Yoon JH, Jung SY, Kim W et al (2006) Nesterenkonia jeotgaki sp. nov., isolated from jeotgal, a traditional Korean fermented seafood. Int J Syst Evol Microbiol 56:2587-2592. https://doi.org/10.1099/ijs.0. 64266-0

Zannier F, Portero LR, Ordoñez OF et al (2019) Polyextremophilic bacteria from high altitude Andean lakes: arsenic resistance profiles and biofilm production. Biomed Res Int 2019:1231975. https:// doi.org/10.1155/2019/1231975

Zannier F, Portero LR, Douki T et al (2021) Proteomic signatures of microbial adaptation to the highest UV-irradiation on earth lessons from a soil actinobacterium. bioRxiv. https://doi.org/10. 1101/2021.07.11.451938

Ziebuhr J, Snijder EJ, Gorbalenya AE (2000) Virus-encoded proteinases and proteolytic processing in the Nidovirales. J Gen Virol 81:853-879. https://doi.org/10.1099/0022-1317-81-4-853

Zuber B, Haenni M, Ribeiro T et al (2006) Granular layer in the periplasmic space of gram-positive bacteria and fine structures of Enterococcus gallinarum and Streptococcus gordonii septa revealed by cryo-electron microscopy of vitreous sections. J Bacteriol 188:6652-6660. https://doi.org/10.1128/JB.00391-06

Publisher's Note Springer Nature remains neutral with regard to jurisdictional claims in published maps and institutional affiliations. 